\title{
Die oorsprong van Israel volgens resente navorsing 1
}

\author{
Nic van der Westhuizen \& Hannes Olivier \\ Departement Ou Testament \\ Universiteit van Stellenbosch \\ STELLENBOSCH
}

\begin{abstract}
Alstrac
A debate regarding the origin of Israel gave rise to much controversy which developed during the iwenties. This debate saw an upsurge of interest during the sixies and seventies. Researchers identified themselves with three schools of thought. In this article negative as well as posilive elements in the various schools are focused on. Consensus has been reached by researchers that the greatest obstacle in the way of the reconstruction of Isnael's earty histon' is the lack of ierifiable sources. This study has looked for a new key, i.e. the creation of a broad scenario of the life in Canaan during the transition of the Late Bronze Age to the Iron Age I. If such a scenario could be reconstnucted as correclly as possible, it would be possible to establish the conditions of Israel's origins. This study intends to play an elucidating role, illustrating the ways in which the people of Canaan lived and worked in the Late Bronze Age and Iron Age, for it was under these circumstances that Israel had its origins.
\end{abstract}

\section{INLEIDING}

Sedert die ontstaan van die debat rondom die inname van die land, die vestiging daarin en die oorsprong van Israel het alle standpunte of teorieë oor die oorsprong van Israel hoofsaaklik in drie modelle uitgekristalliseer, naamlik:

die militêre-innamemodel van die Baltimoreskool;2

die vrecdsame-infltrasiemodel van die Leipzigskool;3

die interne-opstandmodel van die Sosiologieskool. ${ }^{4}$

1 Enkele belangrike publikasies wat onlangs verskyn het, kon ongelukkig nic in dic artikel verwerk word nic omdat hulle te laat verskyn het. Ter wille van volledighcid word hulle genoem aangesien die publikasies nuwe lig op die probleem kan werp. The Canaanites and their Land. The Tradition of the Canaanites (Lemche, 1991). Archaeology of the Land of the Bible 10000-586 BCE (Mazar, 1990). Out of the Desert? Archaeology and the Exodus/Conquest Narratives (Sticbing, 1989). Recent Archaeological Discoveries and Biblical Research (Dever, 1990).

2 Hicrdic model vind sy oorsprong in die standpunt van veral W.F. Albright. Wright (1946), Bright (1983), Lapp (1967), Malamal (1982) en Yadin (1982) het almal 'n belangrike bydrac gelewer om dic model van dic Baltimoreskool te propageer.

3 Hierdic model vind sy oorsprong veral in die standpunte van A. All (1953a \& b en 1966) en M. Noth (1930, 1960a cn 19602 b). Aharoni (1971 cn 1976), Weippert (1971 en 1979), Fritz (1980, 1981 en 1983), Herrmann (1985), Zertal (1986) en Finkelstein (1988a en 1988b) het almal rcuse-werk gedoen om die rreedsame-infiltrasiemodel op vaste fondamente te plaas. 
Tans kan ' $n$ vierde skool onderskei word wat van die standpunt uitgaan dat nie een van die bogenoemde modelle korrek is nie. ${ }^{5}$ Volgens hierdie 'nuwe' skool moet die oorsprong van Israel eerder gesoek word in die sameloop van baie omstandighede wat nie maklik uit die literêre of argeologiese materiaal afgelei kan word nie.

In the furst place we are cautious to say anything. The evidence, or lack of evidence, is such that confident treatment of the origins of Israel and Judah in terms of critical historiography is, in our opinion, simply impossible. (Miller \& Hayes 1986:78.)

Dit het uit die navorsing van die verskillende skole duidelik geblyk dat nie een van die standpunte heeltemal verwerp kan word nie. Elkeen het 'n belangrike faset van Israel se geskiedenis beklemtoon. Die ontstaansgeskiedenis van Israel kan slegs sinvol bestudeer word as die verskillende standpunte van die onderskeie skole in ag geneem word, dit krities bestudeer en die positiewe elemente daarin benut word. Die oplossing van die probleem is daarin geleë dat ' $n$ multi-dimensionele benadering gevolg word. So kan elke veranderlike wat moontlik ' $n$ invloed op Israel se onstaansgeskiedenis uitgeoefen het, wetenskaplik geëvalueer en in berekening gebring word.

\section{TEORIEē OOR DIE OORSPRONG VAN ISRAEL 6}

\section{Die Baltimoreskool}

Die militêre-innamemodel van die Baltimoreskool vind sy beslag in die standpunt van Albright wat, op grond van sy argeologiese navorsing by verskillende tels in Kanaän, tot die gevolgtrekking kom dat die oorsprong van Israel gesoek moet word in 'n groot militêre offensief van 'n groep mense wat aan die einde van die dertiende eeu v.C. talle Kanaänitiese stede ingeneem en verwoes het. ${ }^{7}$ Op die ruines van hierdie stede sou die 'nuwe' intrekkers nedersettings bou wat 'n merkbare laer peil van kulturele ontwikkeling weerspieël as hulle onmiddellike voorgangers. Volgens Albright en

4 Hierdie model vind sy oorsprong in veral die standpunte van G.E. Mendenhall (1962 en 1973) en N.K. Gollwald (1974, 1978a, 1979, 1983 en 1985). Chaney (1983), I cmche (1985) en Ahlstrōm (1986) lewer 'n belangrike bydrac om die Sosiologieskool die nodige onderbou te verskaf.

5 Herrmann (1985:65-81) sien nie die standpunt wat Miller en Hayes in A History of Ancient Israel and Judah (1986) inneem as 'n vierde model nie. Hy verkies om ecrder die standpunt van Lemche soos wat dit tot uiting kom in sy Early Israel: Anthropological and Historical Studies on the Israelite Society Before the Monanchy (1985) as die vierde model te beskou. Hy noem dit, in teenstelling met Gottwald, die evolusiemodel van Lemche.

6 In hierdie artikel sal daar nie aandag gegee word aan al die verteenwoordigers van die verskillende skole nie. Daar sal alleenlik aandag gegee word aan die slandpunte van die persone wat die verskillende skole gevestig het. (ieleerdes wat by die verskillende skole aansluiting gevind het, word slegs ter wille van volledigheid genoem.

7 Vit 'n volledige bespreking van die belangrikste tels waar verteenwoordigers van die Baltimoreskool navorsing gedoen het, vergelyk Van der Westhuizen (1991:15-38). 
ander verteenwoordigers van die Baltimoreskool is daar 'n duidelike korrelasie tussen hierdie gebeure en die gebeure waarvan daar in Josua 1-12 melding gemaak word. Die inname van die land geskied dus in 'n relatief kort periode waarby alle Israelitiese stamme betrokke was. Op hierdie wyse probeer die Baltimoreskool om die weergawe van Josua 1-12 deur die argeologiese bewyse te sanksioneer (Albright, 1935:10-18, 1939:11-23; Yadin, 1982:17; Malamat, 1982:25 en Pienaar, 1990:311-312).

Die verwoesting van die Kanaänitiese stede in die Laat Bronstyd, ${ }^{8}$ unieke keramiekware ${ }^{9}$ en argitektoniese eienskappe van die geboue in die nuwe nedersettings, ${ }^{10}$ die militêre haalbaarheid van die operasie ${ }^{11}$ en talle opgrawingsprojekte is van die belangrikste redes wat die Baltimoreskool aanvoer as bewys van hulle standpunt. ' $n$ Volledige bespreking van die punte van kritiek ten opsigte van die kriteria wat aangewend word as bewysplaas vir die model van 'n vinnige verowering en besitname van die land val buite die skopus van die artikel.12

Die belangrikste gesigspunte kan soos volg saamgevat word:

- Verwoesting kan nic aan 'n spesifieke etniese groep verbind uord nie

Daar kan nie genoegsame bewyse gevind word dat die Israeliete as 'n nomadiese of semi-nomadiese groep die gebied aan die westekant van die Jordaanrivier verower het nie. Geen afdoenbare bewyse bestaan dat dit nou juis die Israeliete was wat die Kanaänitiese stede verwoes het nie. Argeologiese data wat by die meeste stede ingesamel is, ${ }^{13}$ klop nie met ' $n$ dertiende-eeuse datering van die intog nie. Pogings om die datering van die verwoesting van die stede te verhoog of te verlaag, het ook nie die probleem opgelos nie (Callaway, 1968:312-320; Waltke,

8 Noort (1987:92), Miller \& Hayes (1986:71-72), Finkelstein (1988b:295), London (1989:38-39) en Lemche (1985:57).

9 Albright (1937:25 en 1971:118), Noort (1987:95-96), London (1989:42-44) en Fritz 1987:9698).

10 Shiloh (1970:182-184 en 190).

11 Yadin (1982:17-23) en Malamat (1982:25-35) beklemtoon dat goeie verkenning en voorbereidings die veroweringstog vooral gegaan het. Logisticke beplanning, slim diplomasie en sielkundige oorlogvocring het ook 'n belangrike rol gespeel in die verowering van die Kanaänitiese stede.

12 Vir 'n volledige bespreking hicrvan vergelyk Van der Westhuizen (1991:38-45).

13 Die gegewens wat by Hasor, Lagis en Bet-El ingesamel is, is dic enigsle vilsondering op die reęl. Daar is duidelike aanduidings dat hicrdie stede wel teen die einde van die derliende eeu v.C. verwoes is. Dit is cgicr nie moontlik om die verwoesting op grond van argeologiese data met 'n spesifieke etniese groep te verbind nie (Van der Westhuizen, 1991:46). 
1972:33-47; Bimson, 1978:147 e.v.; Miller, 1977a:88; Leonard, 1989:4-39 en Wood, 1990:57). Die geskiedenis aan die einde van die Laat Bronstyd staan in die teken van agteruitgang op alle gebiede van die samelewing wat veroorsaak is deur politieke en ekonomiese beroeringe op internasionale skaal. Die agteruitgang van die meeste Kanaänitiese stadstate gedurende die laaste fase van die Laat Bronstyd kan hieraan toegeskryf word. Dit is onwaarskynlik dat alle verwoestings verband hou met die optrede van die Israeliete soos wat dit in Josua 1-12 aan ons voorgehou word en deur die Baltimoreskool beklemtoon word.

- Beklemtoning van die argeologie ten koste van literêre bronne

Die Baltimoreskool is ook daartoe geneig om die argeologie as hulle belangrikste bron ten koste van die literère bronne te beklemtoon (Soggin, 1960:95-100; Pienaar, 1990:312 en 317; Miller, 1985:20 en Sauer, 1982:205-209). Dit beteken nie dat die argeologie as bron geheel en al verwerp moet word nie. In die jongste tyd het dit waardevolle inligting gebied ten opsigte van die daaglikse leefwyse in Kanaän gedurende die oorgang van die dertiende eeu v.C. na die twaalfde eeu v.C. (Van der Westhuizen, 1991:108-109). ${ }^{14}$ Verskillende weergawes van die intog wat in die onderskeie tradisies van die Ou Testament voorkom, word heeltemal geignoreer of wegverklaar (Bimson, 1989:6 en Chaney, 1983:46). Dit is jammer dat die Baltimoreskool nie meer van ander vakdissiplines gebruik gemaak het in hulle navorsing oor die oorsprong van Israel nie. Dit is veral die vroeëre verteenwoordigers van dié skool wat hulle hieraan skuldig gemáak het. Die Antropologie, Ekonomie, Sosiologie, Geografie, ensovoorts, kon dié skool ongetwyfeld van waardevolle ontsluitingsmodelle voorsien het (Sauer, 1982:203-204; Ben Tor, 1979:105 en Pienaar, 1990:314).

\section{- Metodologiese argumentasiefoute}

Bepaalde metodologiese foute kan ook in die argumentasie van die Baltimoreskool aangewys word. ${ }^{15}$ Twee verskillende leefwyses en kulture, naamlik 'n Kana-

14 Miller het veral hierdie funksie van die argeologie beklemtoon. Die argeologie moet nooit ingespan word om die Bybelse tradisie oor die oorsprong en geskiedenis te waarmerk nie. Die argeologie moet ingespan word om die navorser 'n idee te gee oor hox die mense van die tel of area wat opgegrawe word elke dag geleef en gewerk het. Op hicrdic wyse bied dic argeologie waardevolle inligting oor toestande in die Laat Bronstyd en Ystertyd wat hier ter sake is.

15 Dit was hierdie verskillende metodologiese uitgangspunte wat daarvoor verantwoordelik was dat die Baltimoreskool baie minder daartoe bereid was om ver van die Bybelse weergawe van die inname soos wat hulle dit verstaan het, weg te beweeg, en altyd bereid was om aanpassings te maak ten opsigte van dic buite-Bybelse gegewens om die Bybelse weergawe van die oorsprong van Isracl te akkommodecr. Daarenteen was dic Leipzigskox)l lereid om 'n baie meer kritiese houding in te neem tecnoor die Bybelse weergawe van dic oorsprong van Israel. Hulle huiwer nie om kritiek Ieenoor die Bybelsc weergawe uit te spreck nie. 
änitiese stadskultuur en 'n oorheersend landelike 'Israelitiese' kultuur word met mekaar vergelyk. Die kultuurbreuk tussen die Laat Bronstyd en Ystertyd is ook nie so opvallend as wat die Baltimoreskool graag voorgee nie (Bimson, 1989:6). Argeologiese getuienis dui op 'n baie groter kontinuïteit as diskontinuïteit (Ahlström, 1986:3). 'n Verdere metodologiese fout wat die Baltimoreskool in hulle argeologiese navorsing begaan, is om in hulle navorsingswerk slegs op enkele van die groter tels te konsentreer en dié afleidings op alle tels (klein en groot) van toepassing te maak (Sauer, 1982:201-202 en Van der Westhuizen, 1991:109). Kleiner tels in Transjordanië sowel as dié op Kanaänitiese bodem verdien ook die aandag van argeoloë. Die verandering in die aard en gehalte van die keramiekware wat deur die Baltimoreskool as 'n kultuurverandering geïdentifiseer word, kan nie net daaraan toegeskryf word nie. Nuwe vestigingspatrone en argitektoniese ontwikkelings kan nie met etniese verandering in verband gebring word nie. Veranderinge wat teweeggebring word deur faktore soos 'n veranderde leefwyse, wisselende ekonomiese toestande en nuwe tegnologiese uitvindings, word nie genoegsaam deur die Baltimoreskool verreken nie (Noth, 19602b:262-282).

- Verwoeste stede nie dadelik herbou nie

Dit moet ook bevraagteken word of die stede wat volgens die Baltimoreskool ingeneem en verwoes is, onmiddellik herbou is. Argeologiese gegewens dui daarop dat die meeste stede wat verwoes is nie dadelik herbou is nie, maar vir 'n geruime tyd onbewoond gelaat is. So bevind Finkelstein (1988b:101) dat selfs Hasor (wat dikwels as die handboekvoorbeeld gebruik is in die argumentasie van die Baltimoreskool) vir 150 tot 200 jaar onbewoond gelaat is nadat dit aan die einde van die dertiende eeu v.C. verwoes is. 10 Dit is uit die argeologiese navorsing duidelik dat daar meer ruimte gelaat sal moet word vir 'n langer proses waardeur die land ingeneem en finaal beset is. Die kort maar kragtige militêre offensief waardeur die land volgens die weergawe Josua 1-12 ingeneem en verower is, word deur geen argeologiese navorsing gerugsteun nie.

\section{- Subjektiewe intepretasie van argeologiese materiaal}

Daar moet egter altyd in gedagte gehou word dat die argeologiese inligting wat ingesamel is, gewoonlik na analogie van dit wat ons reeds weet, geïnterpreteer word (Miller, 1982:211). Die gevaar van subjektiwiteit bestaan ook ten opsigte van die interpretasies van argeologiese materiaal. Interpretasies bly hipoteties totdat

16 Dit is slegs in die geval van Tel Beit Mirsin, Tel Zeror en Bet Semes dat tekens gevind kon word wat daarop dui dat die stede onmiddellik nadat hulle verwoes is, weer opgebou en bewoon is. In al drie gevalle was die nuwe fase van bewoning van korte duur, en is die stede gou weer onbewoond agtergelaat. Die rede hicrvoor was moontlik gelec̈ in die optrede van die Seevolke in die gebied (Van der Westhuizen, 1991:39-40). 
dit deur feitelike gegewens bevestig word (Miller, 1985:20 en Hodder, 1984:25-31). Foutiewe afleidings van vroeër beïnvloed maklik latere aannames (Weippert, 1971:129-130). Die feit dat daar ook oor die identifisering van sommige tels twyfel bestaan, plaas ' $n$ beperking op die aanwending van die argeologie as hulpmiddel vir die rekonstruksie van die vroeë geskiedenis van Israel. Baie van die stede wat in die innametradisie vermeld word, kon nog nie positief met spesifieke tels in verband gebring word nie. ${ }^{17}$

\section{- Teologiese uitgangspunt}

Die teologiese vertrekpunt van die Baltimoreskool moet ook bevraagteken word.

Those associated with this movement generally argued that the authority of the Bible resides in its overall faith claims and that the validity of these claims is not dependent upon the detailed historical accuracy of the biblical accounts. (Miller 1985:20.)

Hierdie kritiese opmerkings oor die standpunt van die Baltimoreskool vereis nie dat alle bevindinge van die Baltimoreskool geheel en al verwerp moet word nie. Waardevolle werk is deur dié skool gedoen. Sonder die bydrae van die Baltimoreskool sou ons kennis van die vroeë geskiedenis van Israel beslis armer gewees het.

\subsection{Die Leipzigskool}

Hierdie skool vind sy oorsprong in die Duitse wêreld na aanleiding van die vraagstelling ten opsigte van die oorsprong van Israel (Soggin, 1960:95-96). Die metodologiese en teologiese uitgangspunte van die Leipzigskool het op baie vaster fondamente gestaan as die van die Baltimoreskool. Hulle beklemtoning van die Bybelse teks as ' $n$ belangrike basis waaruit die vroeë geskiedenis van Israel verstaan moet word, moet waardeer word (Pienaar, 1990:311-312). Hulle verskil van die Baltimoreskool deurdat hulle nie huiwer om die Ou Testament se weergawe van die intog in Josua 1-12 te bevraagteken waar dit nie deur genoegsame feitelike gegewens bevestig kan word nie. Die Leipzigskool plaas 'n baie groter premie op die weergawe van die inname soos wat dit in Rigters 1-2 opgeteken is as die weergawe in Josua 1-12.

Reeds in 1925 publiseer Alt "Die Landnahme der Israeliten in Palästina" wat verreikende gevolge ingehou het vir die bestudering van die geskiedenis van Israel (vgl. Alt, 1953c:89-125). Dit word later opgevolg deur twee ander artikels, naamlik "Josua" (1936; vgl. Alt, 1953b:176-192) en "Erwägungen über die Landnahme der Israeliten in Palästina" (1939; vgl. Alt, 1953a:126-157). As gevolg van 'n gebrek aan goeie bronne vir die rekonstruksie van Israel se ontstaansgeskiedenis, bepleit Alt 'n deeglike herwaardering van alle bestaande bronne. Die ruim tydsverloop tussen die werklike gebeure en die opskrifstelling daarvan verplig Alt om die verifieerbaarheid van die

17 Vergelyk in die verband die artikel van Miller The Witness of Ai* (ongepublisecrd) waarin die probleem met betrekking tot Bet-El en Ai breedvoerig behandel word. 
historiese tradisies van die Ou Testament te bevraagteken. Alle beskikbare bronne moet volgens Alt benut word. Daarom kan hy hom nie nét op die argeologie as bron verlaat nie. Ily pleit vir 'n deeglike ondersoek van alle relevante inligting 18 wat moontlik 'n lig kan werp op die vroeë geskiedenis van Israel (Lemche, 1985:39). Verwante vakdissiplines moet ook in die navorsingsproses ingespan word om alle moontlike inligting te bied oor die gebied waarin Israel hulle gevestig het. ${ }^{19}$

Alt bepleit 'n studie wat hy 'die studie van die territorial divisions' 20 noem. Dit beteken dat die geskiedenis van die geografiese gebied waarin Israel hulle gevestig het deur middel van alle beskikbare bronne - literêr en argeologies - bestudeer moet word.

Only when we have ascertained the state of territorial divisions that were developed and established before the Israelites appeared, and work back from the forms they took in the period that followed, in order to find out what remained of the old divisions and what was altered, can we make a true cstimate of the effect of the settlement on the political geography of the country. (Alt, 1966:136.)

Alt het bevind dat Egipte gedurende laaste fase van die Laat Bronstyd sy beheer oor ' $n$ groot aantal Kanaänitiese stadstate verloor het. Gelyktydig hiermee is daar 'n merkbare toename in die getal nuwe nedersettings in veral die hoërliggende gebiede van Kanaän ${ }^{21}$ sowel as in die droër gebiede in die oostelike gedeeltes; dit wil sê die gebiede wat aan die begin van die Laat Bronstyd yl bevolk was. Op grond hiervan kom Alt tot die volgende gevolgtrekking oor die vroeë geskiedenis van Israel:

Israel vind sy oorsprong in klein individuele nomadiese of semi-nomadiese groepe wat in die gebied aan die oostekant van die Jordaan rondtrek. Gedurende die droër maande trek hulle oor die Jordaan agter beter weiveld vir hulle vee aan. Hulle kom later eers in kontak met die Kanaäniete wat hoofsaaklik in die stadstate op die vlakte woon. Die aanvanklike proses verloop vreedsaam aangesien die 'nuwe' intrekkers geen bedreiging vir die Kanaänitiese stadstate inhou nie. Hulle vestig hulle hoofsaaklik in die yl bevolkte gebiede wat veral geskik is vir kleinveeboerdery. As gevolg van gebrek aan beskikbare lewensruimte en 'n wedywering om goeie grond wat geskik is akkerbou, ontstaan konflikte met die

18 Hy sluit hicrby in Bybelse en buite-Bybelse literête bronne. In hierdie opsig neem Alt 'n heeltemal ander vertrekpunt in as byvoorbeeld die Baltimoreskool wat in hulle navorsing hulle hoofsaaklik beperk het to Josua 1-12.

19 Lemche (1987:128) wys daarop dat hicrdie benadering wat Alt en ander verlecnwoordigers van dic Leipzigskool bepleit, nic so nuut is as wal dikwels aanvaar word nic. Lemche wys daarop dal so 'n 'nuwc' benadering reeds so vroeg as 1878 opgemerk word by OuTestamentici soos Wellhausen, Stade, Guthe, Steucrnagel en Meyer.

20 Tcritorialgeschichtliche Fragestcllung".

21 Die hočrliggende gebiede sluit veral die bergagtige gebiede in die noorde, suide cn sentrale gebicde van Kanaăn in. 
inheemse Kanaănitiese bevolking. Alt onderskei dus twee duidelike fases in die innameproses, naamlik: (1) 'n Aanvanklike vreedsame proses, die sogenaamde Landnahme-fase en (2) ' $n$ latere fase wat meer geweldadig verloop het, die sogenaamde Landesausbau-fase.

Eersgenoemde fase verloop rustig en sonder enige konflik. Laasgenoemde fase word gekenmerk deur sporadiese voorvalle van konflik wat gemik was teen die inheemse plaaslike bevolking: die Kanaäniete. Die weergawe van die inname soos wat dit in Josua 1-12 gevind word, het volgens Alt hoofsaaklik betrekking op die Landesausbaufase (Finkelstein, 1988b:302-306; Miller \& Hayes, 1986:77; Lemche, 1985:42). Tydens hierdie fase word daar al meer gesteun op akkerbou as die belangrikste bron van lewensonderhoud. Kleinveeboerdery het gevolglik 'n minder belangrike rol begin speel. In die proses word daar nie meer hoofsaaklik na goeie weiveld gesoek nie, maar eerder na beter landbougrond wat geskik is vir akkerbou-doeleiendes. Laasgenoemde grond was veral geleë in die laerliggende gebiede wat baie digter bewoon was as die hoërliggende gebiede. Hieruit het sporadiese konflikte gevolg.

Noth, een van Alt se studente, het in 'n groot mate by hom aangesluit. Hy beskryf die eerste Israeliete as landhonger nomadiese mense. Net soos Alt beklemtoon hy dat die intog aanvanklik gekenmerk is deur 'n vreedsame besetting van die yl bevolkte gebiede (Noth, 1960²b:69). Hy lewer soos Alt ook kritiek op die wyse waarop die Baltimoreskool die argeologie gebruik as bron vir die vroeë geskiedenis van Israel. Noth en Alt verskil hoofsaaklik van mekaar deurdat Noth sy sogenaamde amfiktionie-hipotese gebruik om die vroeë geskiedenis van Israel te rekonstrueer. Hiervolgens het geen stamvorming plaasgevind voordat die Israeliete hulle in Kanaän gevestig het nie. Die individuele stamme het dus hulle finale beslag op Palestynse bodem gekry. Alt gaan van die standpunt uit dat stamvorming reeds sy beslag vind voordat die Israeliete Kanaän betree het.

Aharoni (1971:94-128 en 1976:55-76), Weippert (1971 en 1979:15-34), Zertal (1986), Fritz (1980:121-135; 1981:61-73, 1983:15-21 en 1987:96-97), Herrmann (1985:47-53) Finkelstein (1988a:34-45 en 1988b:336-351) en De Vaux (1978:475-481) het almal 'n belangrike bydrae gelewer om die vreedsame-infiltrasie-teorie van die Leipzigskool te propageer. In hulle benadering kry veral Rigters 1-2 aandag as die mees betroubare weergawe vir die inname van Kanaän. Die konflik waarvan daar veral in Josua 1-12 sprake is, beeld volgens dié skool slegs die finale fase van die inname uit, toe die eerste Israeliete met die inheemse Kanaänitiese bevolking gebots het as gevolg van gebiedsuitbreiding.

Die belangrikste kritiek teen die Leipzigskool kan in die volgende punte saamgevat word. 


\section{- Nomadisme as bestaanswyse}

Dit is jammer dat die Leipzigskool22 'n moderne sosiale verskynsel soos 'n Bedoeïen-leefwyse gebruik om die semi-nomadiese of nomadiese leefwyse van die eerste Israeliete aan die einde van die Laat Bronstyd of begin van die Ystertyd te beskryf (Donner, 1984:124; Noort, 1987:88; Callaway, 1988:71; Lemche, 1985:46; Mendenhall, 1962:68-69; Weippert, 1971:106-107 en Finkelstein, 1988b:304). Die vooronderstelling waarop die Leipzigskool hulle hipotese bou, naamlik dat die eerste Israeliete hulle oorspong vind in die jaarlikse semi-nomadiese of nomadiese migrasies agter weiveld aan, kan nie langer verdedig word op grond van die nuwe beskouing oor die nomadisme as sosiale verskynsel nie..$^{23}$

- Onvoldoende aandag aan verwante vakdissiplines

Kritiek deur die Baltimoreskool en Sosiologieskool dat die Leipzigskool nie genoegsaam aandag gegee het aan die Argeologie, Ekonomie, Antropologie, Sosiologie en ander verwante vakdissiplines, kan nie aanvaar word nie. Lemche (1985:37), Weippert (1971), Ahlström (1990:81) en Finkelstein (1988b:303) het genoegsaam aangetoon dat die Leipzigskool wel van hierdie vakdissiplines gebruik gemaak het. 24

- Leemtes in die amfiktionie-hipotese

Die wyse waarop Noth deur middel van sy amfiktionie-hipotese die vroeë geskiedenis van Israel probecr rekonstrueer het, het heeltemal tereg baie kritiek ontlok. Die wyse waarop Noth 'n sosiale verskynsel uit 'n ander kultuur en teen 'n ander historiese agtergrond net so op Israel van toepassing maak, kan nie aanvaar word nie. "The hypothesis of the amphictyony is now irrelevant to the investigation into Israel's past history." (Lemche, 1984:21.) Die amfiktionie-hipotese speel in onlangse navorsing oor die vroeë geskiedenis van Israel byna geen rol meer nie.

22 Hier hel dit veral belrekking op die slandpunte van Alt en Noth.

23 Vir ' $n$ volledige bespreking van nomadisme as sosiale verskynsel vergelyk Van der Westhuizen (1991:174-191). Vergelyk in die verband ook die kritiek wat Donner (1984:124. 125) en Chancy (1983:43) uitspreck op Alt en Noth se verstaan van die nomadisme as bestaanswyse. Dil is duidelik dat Donner nie probleme ondervind met die nomadisme as moontlik oorsprong vir die ecrste Isracliete nie. Hy verskil egter van Alt en Noth oor die wyse waarop hulle nomadisme verstaan.

24 Dit moct beklemtoon word dal die Leipzigskool nie op presies dieselfde wyse as navorsers in die laal sewentiger- en lagligerjare van hierdie vakdissiplines gebruik gemaak het nie. Lemche (1985:37) som die gebruik van die verwanle vakdissiplines deur die vroeère verleenwoordigers van dic Leipzigskool soos volg op: "... Alt and Noth were well informed on the suciology and anthropology of their day." 
- 'Landhonger' 'n tiperende kenmerk van die landbouer

Die sogenaamde 'landhonger' van die eerste Israeliete waarvan Noth melding maak, is volgens Wolff (1966:25 e.v.) en Bimson (1989:9) eerder die kenmerkende eienskap van 'n landbouer as 'n nomadiese of semi-nomadiese (klein)veeboer. Die semi-nomadiese of nomadiese veeboer kon in baie ongunstiger omstandighede 'n bestaan voer, terwyl die landbouer wat hom op akkerbou toegespits het, afhanklik was van goeie bewerkbare grond. Dit het hom genoodsaak om altyd daarna op soek te wees. Op grond van nuwere navorsing sou dit foutief wees om van die vooronderstelling uit te gaan dat die eerste Israeliete in Kanaän slegs 'n bestaan gevoer het as semi-nomadiese of nomadiese veeboere. Dit is onrealisties om te dink dat die Arabiese woestyn 'n onbeperkte bron van mense sou kon oplewer wat die gebied aan die westekant van die Jordaan sou onrstroom en beset het. Dié woestyngebied sou eenvoudig nie vir 'n lang tyd so 'n groot hoeveelheid mense en hulle veekuddes kon huisves nie - mense wat volgens die Leipzigskool oor 'n tydperk van so lank as tweehonderd jaar hulle permanent in Kanaän gevestig het.

Tog het die benadering van die Leipzigskool dit beklemtoon dat daar nie sonder meer van 'n pan-Israelitiese verowering van die gebied gepraat kan word nie. Die Leipzigskool het dit beklemtoon dat daar argeologies nie genoegsame bewyse be staan vir 'n groot Israelitiese militêre inval aan die einde van die dertiende eeu v.C. nie. Hulle het heeltemal tereg beklemtoon dat daar ook ruimte gelaat moet word vir 'n geleidelike infiltrasie van die gebied aan die westekant van die Jordaan. Die historiese verifieerbaarheid van die inhoud van Josua 1-12 is nie moontlik nie. Daar sal eerder aandag gegee moet word aan die weergawe van die inname soos wat dit in Rigters 1-2 na vore kom.

\section{Die Sosiologieskool}

Die modelle van die Baltimore- en Leipzigskole het die terrein van die navorsing oor die vroeë geskiedenis van Israel vir byna dertig jaar oorheers. Ten spyte van onderlinge verskille tussen die twee skole gaan albei van een gemeenskaplike standpunt uit, naamlik dat die oorsprong van Israel iewers buite Kanaän gesoek moet word. Hulle verskil slegs van mekaar wat betref die wyse waarop Israel vastrapplek in Kanaän bekom het (Lemche, 1985:2).

In 1962 publiseer Mendenhall 'n artikel wat die grondslag gelê het vir 'n nuwe benadering in die navorsing oor die vroeë geskiedenis van Israel. 25 Hy wys veral op twee foutiewe vooronderstellings waarmee die Baltimore-en Leipzigskole gewerk het,

25 The Hebrew Conquest of Palestine" (Mendenhall, 1962:66-87). Hy het die model verder uitgebrei en verwerk in 'n boek wat in 1973 verskyn het - The Tenth Generation: The Origins of Biblical Tradition. 
naamlik: (1) Nomades se voortdurende hunkering na permanente vestiging omdat dit volgens die Baltimore-, maar veral die Leipzigskool, 'n verbetering in lewenstandaard sou beteken. (2) Hierdie langverwagte permanente vestiging sou noodwendig op een of ander stadium aanleiding gegee het tot konfliksituasies met die plaaslike inheemse inwoners van die gebied waarin die eerste Israeliete hulle gevestig het. Mendenhall se nuwe benadering het veral in die Amerikaanse wêreld groot byval gevind. Gottwald sou in dié verband vanaf die sewentigerjare 'n reuse-bydrae lewer om die nuwe intermeopstandmodel verder uit te werk en te propageer (Gottwald, 1974:223-255;26 1975:89100; 1978b:37-52 en 1979). De Geus (1976), Ahlström (1982:13-138 en 1986), Chaney (1983) en Lemche (1985) het met aanpassings diê model ondersteun.

Volgens die Sosiologieskool moet die oorsprong van die Israeliete nie in die nomadiese of semi-nomadiese groepe van die Arabiese woestyn buite Kanaän gesoek word nie, maar op Kanaänitiese bodem self. Israel se oorsprong is geleë in die inheemse Kanaänitiese bevolking. Gemeenskaplike vyande 27 het later tot 'n verbondenheid tussen die eerste 'Israeliete' en die inheemse Kanaänitiese boerebevolking aanleiding gegee (Mendenhall, 1962:66-67). As gevolg van hulle lewensomstandighede ontwikkel daar 'n simbiotiese leefwyse tussen die Israeliete en die Kanaänitiese boerebevolking. Hulle het in mekaar se daaglikse behoeftes voorsien. Daarom beweer Mendenhall dat dit nie moontlik was om tussen landbouers en veeboere 'n duidelike onderskeiding te tref nie. Stamvorming vind nie plaas as gevolg van genealogiese verbintenisse nie, maar spruit voort uit 'n subjektiewe gevoel van 'behoort aan' en 'lojaliteit aan' sake van gemeenskaplike belang. Dit beteken dat stamme uit mense kan bestaan wat verskillende etniese groeperinge insluit. Dit was veral in hierdie verband dat die Hebreërs ('Apiru) vir Mendenhall 'n baie belangrike rol speel. ${ }^{28}$ Die 'Apiru was 'n groep mense afkomstig uit alle dele van die samelewing wat in opstand gekom het teen die onderdrukkende maatreëls van die Kanaänitiese stadstate. ${ }^{29}$ Volgens Mendenhall moet die oorsprong van die eerste Israeliete hier gesoek word.

Gottwald het op 'n baie meer akademies-verantwoordbare manier probeer om die geskiedenis van die sosiale omstandighede aan die einde van die dertiende eeu v.C. daar

26 Die artikel kom gewysig in Gollwald 1978a:2-7 voor.

27 Hier moet veral gedink word aan onderdrukking deur die Kanaänitiese stadstaatheersers van die bevolking wal as landbouers en veeboere 'n bestaan gevoer hel.

28 Dit is opmerklik dat van al die verteenwoordigers van die Sosiologicskool, dit slegs Mendenhall is wat ' $n$ belangrike rol aan die 'Apin loeken in die navorsing oor die vroec geskiedenis van Israel. Mendenhall is deur feitlik alle Ou-Testamentici op hierdie punt gekriliseer, selfs vanuil geledere van die Sosiologieskool.

29 Die Kanaänitiese stadstate was gedurende die Laat Bronstyd grontliks onder beheer van Egipłe. Die Kanaānitiesc stadslaathecrsers moes direk aan die farao in Egiple verslag doen. 
te stel. Hy maak baie gebruik van beproefde sosiologiese en antropologiese navorsingsmetodes (Miller, 1982:215), en beklemtoon dit vir die eerste maal baie sterk dat die oorsprong van Israel nie buite Kanaän gesoek moet word nie, maar in 'n ingewikkelde proses van revolusie en evolusie wat binne die inheemse Kanaănitiese samelewing plaasgevind het. Israel was nie afkomstig uit 'n homogene groep mense nie, maar uit 'n heterogene groep wat binne Kanaän gewoon het, en deur die Kanaänitiese heersersklas uitgebuit is. Dit het aanleiding gegee tot 'n proses wat hy retribalization noem (Otto, 1988:226). ${ }^{30}$ In die geval van Israel het Jahwisme in die oorgangsfase 'n baie belangrike rol gespeel; daarom kan Israel in hierdie oorgangfase ook nie buite dié geloofsverband verstaan word nie.

Israel vind dus nie sy oorsprong in die inval of geleidelike infiltrasie van Kanaän deur 'n vreemde, etnies-homogene groep mense nie, maar in die geleidelike onttrekking van ontnugterde inwoners uit die Kanaänitiese stadstate. Die onttrekking het plaasgevind uit gebiede wat relatief dig bevolk was na gebiede met 'n laer digtheidsyfer. Die nomadiese oorsprong van Israel is gevolglik heeltemal deur Gottwald verwerp as belangrikste bron vir die eerste Israeliete.

Dié model van die Sosiologieskool is met 'n groot mate van skeptisisme ontvang. Fohrer (1977) maak in sy geskiedenis van Israel nie eens melding van die model nie. ${ }^{31}$ Gunneweg (1972) maak wel van die model melding, maar beoordeel dit nie eens nie. Miller (1977b), Thompson (1978) en Hauser (1978) is die eerste persone wat die model van die Sosiologieskool in diepte analiseer en kritiek daarop lewer. Die belangrikste kritiek kan in die volgende aantal punte saamgevat word:

\section{- Foutiewe assosiasie van 'Apinu met die Hebreërs}

Mendenhall het heeltemal foutiewelik die 'Apinu met die Hebreërs (clbrîm) geassosieer. ${ }^{32}$ De Vaux (1978:485-487), Miller (1977b:277-278), Weippert (1971:63-102), Hauser (1978:12-13), Finkelstein (1988b:308-309) en Halpern (1983:51-63) het almal belangrike en deurslaggewende kritiek in dié verband uitgespreek.

30 Dit beteken dat groepe wat ontevrede is oor die omstandighede waarin hulle hulle bevind, terugkeer na 'n vroeëre leefwyse, ten einde in hulle omgewing te kan oorleef.

31 Dit kan moontlik daaraan toegeskryf word dat die model ten tyde van die skryf van die geskiedenis nog nie goed gevestig en uitgewerk was nie. Gunneweg se geskiedenis wal reeds in 1975 verskyn, maak egter wel van die model melding. Dit wil dus voorkom of Fohrer die model as so 'n swak oplossing vir die probleem beskou het dal hy nic eens daarvan melding gemaak bet nie.

32 Dit was slegs Mendenhall as belangrike verteenwoordiger van dic Sosiologicskool wat hierdic assosiasie gemaak het. 
- Onderbeklemtoning van insigte van verwante vakdissiplines

Daar moet ook kritiek uitgespreek word op die wyse waarop die Sosiologieskool van die verwante vakdissiplines gebruik gemaak het in hulle navorsing oor die oorsprong van Israel. Terwyl Ou-Testamentici soos Alt, Noth, Weippert, Miller, ensovoorts, ook die belang van ander vakdissiplines beklemtoon het, gebruik hulle dit altyd in samewerking met die Ou-Testamentiese tradisies wat as een van die beste bronne vir die rekonstruksie van die geskiedenis van Israel beskou word. Hierteenoor wil die Sosiologieskool geen gesag toeken aan die historiese tradisies van die Ou Testament as bron vir die rekonstruksie van Israel se vroeë geskiedenis nie. Sekere fasette van die daaglikse lewe is dikwels ten koste van ander beklemtoon. So speel by sommige verteenwoordigers van die Sosiologieskool die Jahwisme so 'n belangrike rol in die daaglikse lewe dat die invloed van die ekonomie of demografie nie genoegsaam in berekening gebring word nie (Hauser, 1978:6-7; Thompson, 1978:24-25). Dit lei daartoe dat die wyse waarop die Sosiologieskool die samelewing en lewensvorme in die dertiende eeu v.C. interpreteer nie altyd bo verdenking is nie. ${ }^{33}$

- Nomadisme 'n sekondêre sosiale verskynsel

Nomadisme word deur die Sosiologieskool op 'n heel ander wyse verstaan. ${ }^{34}$ Volgens veral Gottwald is nomadisme 'n sekondère sosiale verskynsel wat uit akkerbou ontwikkel het. Hy grond dit op die veronderstelling dat vee tot voordeel van die mens benut kon word eers nadat die grond deur die mens benut is. So word veeboerdery as 'n uitvloeisel van akkerbou beskou (Olivier, 1989:80-81). Dit is in hierdie verband dat Gottwald van die terme retribalization en withdrawal gebruik maak om sy model vir die vroeë geskiedenis van Israel te verduidelik. Gottwald (1979:444-448) wys daarop dat die migrasie dikwels verband hou met trek na die hoërliggende koeler gebiede gedurende die warm droë somermaande en 'n terugkeer na die laerliggende warmer dele gedurende die nat wintermaande. Hy bevraagteken dit of hierdie migrasies slegs verband gehou het met goeie weivelde vir kleinveekuddes soos wat die Baltimore-en Leipzigskole dikwels aanneem. Die Sosiologieskool wys daarop dat dit in 'n droë woestyngebied soos die Arabiese woestyn nie moontlik is om 'n groot getal nomades of semi-nomades te huisves nie. Hulle bevraagteken dit of 'n groot nomadiese of semi-nomadiese groep soos dié waaruit die Israeliete volgens die Baltimore-en Leipzigskool

33 Gebrek aan ruimte verhoed dat die wyse waarop die Sosiologieskool die sosiale omstandighede geinterpreleer het, volledig bespreek word. Die groot onderskeiding wat die skool lussen dic stad en die platleland Iref, kan nie sonder enige kritiek aanvaar word nie. Vir 'n bespreking van die probleem vergelyk Van der Westhuizen (1991:83-85).

34 Vir 'n volledige hespreking van nomadisme as sosiale verskynsel vergelyk Van der Westhuizen (1991:174-191). 
afkomstig was, vir 'n lang periode in 'n droë klimaat sou kon oorleef. Die oorsprong van Israel moet dus nie net buite Kanaänitiese grondgebied gesoek word nie, maar ook in die Kanaänitiese gebied. Pastoral nomadism is vir die Sosiologieskool nie die enigste nomadiese of semi-nomadiese bestaanswyse nie. Nomadiese of semi-nomadiese groepe kon ook in ander vertakkings en bedrywe gevestig gewees het, byvoorbeeld in pottebakkersgildes ensovoorts (Gottwald, 1979:441 e.v.).

\section{- Interpretasie van die Israelitiese stamstnıktuur}

Die wyse waarop veral Gottwald die Israelitiese stamstruktuur interpreteer, het heftige kritiek uitgelok (Otto, 1988:229). Geen duidelike bewyse kan gevind word dat die Israelitiese stamstruktuur 'n skepping van die onderdrukte Kanaänitiese bevolking is wat met die Israeliete geassosieer het ten einde ' $n$ teenvoeter vir die feodaal- en hiërargies-georiënteerde Kanaänitiese stadstaatsisteem daar te stel nie. Die ideaal vir die Sosiologieskool is om die verdrukkende stadstaatsisteem met 'n egalitêre sisteem te vervang waarin niemand ryk is nie, maar niemand ook arm is nie en waar alles aan almal behoort en die gemeenskap saam oor alles besluit. Die Sosiologieskool pas dus 'n moderne sosiale verskynsel of beginsel wat veral in moderne sosialisties-georiënteerde samelewings geld, net so toe op Israel se geskiedenis voor die totstandkoming van die monargie. So 'n vergelyking is nie geldig nie en moet metodologiese bevraagteken word.

- Geen Ou-Testamentiese bevestiging vir 'n inteme-opstandsmodel

Van die belangrikste kritiek wat teen die Sosiologieskool ingebring kan word, is dat daar geen grond in die Ou Testament gevind kan word wat 'n interne-opstandmodel onderskryf nie (Miller, 1977b:279 en Finkelstein, 1988b:307 e.v.) Chaney (1983:52 en 61-67) beskryf die toestande in die oorgang van die Laat Bronstyd na die Ystertyd as ideale omstandighede vir 'n bevolkingsopstand. Die troebel internasionale verhoudinge, die invloei van vreemde volkere in die Ou Nabye Ooste, onderlinge konflikte tussen Kanaänitiese stadstate, swak ekonomiese toestande het vir die onderdruktes van die Kanaänitiese samelewing die geleentheid gebied om hulle onafhanklikheid te bekom. Tegnologiese ontwikkelinge wat plaasgevind het, het dit ook moontlik gemaak om in gebiede te gaan woon wat vroeër onbewoonbaar was. ${ }^{35}$ Chaney (1983:1983:67) wys ook daarop dat die oorheersing van een groep deur 'n ander bevorderlik is vir opstande. Sy verklaring vir die afwesigheid van gegewens wat ' $n$ interne burgerlike opstand steun in die Bybelse tradisie, is nie oortuigend nie. ${ }^{36}$

35 Vir 'n volledige bespreking van die verskillende tegnologiese ontwikkelinge wal plaasgevind het, vergelyk Van der Westhuizen (1991:136-155).

36 Chaney het in die verband daarop gewys dat die afwesigheid van enige gegewens wat 'n interne opstand in Bybelse Iradisie steun, gesoek moet word in die oorsprong van die tradisies. Die tradisies is met 'n heeltemal ander doelwit en oogmerk op skrif gestel. 


\subsection{Die 'Miller-teorie'}

Volgens Miller en Hayes (1986) kan daar drie moontlikhede gebruik word om die vroeë geskiedenis van Israel te rekonstrueer. Ten eerste kan die weergawe van Israel se geskiedenis soos wat dit in Genesis to 2 Konings weergegee word, net so aanvaar word (Miller \& Hayes, 1986:74). ${ }^{37}$ Ten tweede kan die geskjedenis van Israel soos wat dit in die Ou Testament weergegee word, heelternal verwerp word omdat daar van die standpunt uitgegaan word dat die Ou Testament nie 'n goeie histories-verifieerbare bron is nie (Miller \& Hayes, 1986:75). Volgens Miller is dit die beste om nie net met die histories tradisies van dic Ou Testament erns te maak nie, maar om ook ruimte te laat vir sekere aanpassings aan die tradisie waar dit nodig mag blyk te wees (Miller, 1982:214-216).

Ilierdie benadering van Miller het bepaalde gevaarpunte waarop mens bedag moet wees. Daar kan in die proses baie selektief sowel as subjektief met die teks van die Ou Testament omgegaan word. Problematiese tekste kan of geignoreer word of heeltemal onoortuigend verklaar word. Wanneer ander vakdissiplines gebruik word om lig op die probleem te werp, kan 'n subjektiewe ingesteldheid daartoe aanleiding gee dat materiaal so geïnterpreteer word dat die bevindinge by die navorser se uitgangspunt aansluiting moet vind. Dieselfde gevare is ook verbonde aan 'n literêr-kritiese ondersoek van die Ou Testament.

Miller (Miller \& Hayes, 1986:85) beklemtoon dat die argeologie 'n baie belangrike rol speel in die navorsing oor die ontstaansgeskiedenis van Israel. Hy wys egter daarop dat hierdie materiaal nog altyd geinterpreteer moet word, 'n benaderingswyse wat ruimte laat vir verskillende interpretasies. Argeologiese materiaal is slegs van besondere belang waar dit deur literère tekste of inskripsies bevestig word.

Ten spyte van bepaalde tekortkominge soos die vraag oor die historiese verifieerbaarheid van die historiese tradisies in die Ou Testament, bly die Ou Testament vir Miller een van die belangrikste bronne vir die rekonstruksie van die vroeë geskiedenis van Israel. Ondanks die feit dat baie van dié tradisies uiteenlopende uitgangspunte het as gevolg van die groot getal redaktors wat daarvoor verantwoordelik was, het die kern van dié tradisies behoue gebly, en bied dit waardevolle inligting vir enige navorser. Hierdie tradisies moet sover moontlik van mekaar geisoleer word en moet dan as basis dien vir ' $n$ vertrekpunt vir die rekonstruksie van Israel se geskiedenis voor die vestiging van die Monargie. Afleidings wat Miller maak deur van hierdie uitgangspunte gebruik

37 Dit is voor dic hand liggend dat so 'n henadering hom totaai op dic Ou Testament as die enigste betroubare bron vir die geskiedenis van Israel verlaat. 
te maak, dui daarop dat Israel se oorsprong as outochtone gemeenskap nie net buite Kanaän gesoek moet word nie, maar ook op Kanaänitiese bodem of in Kanaänitiese invloedsfeer (Miller \& Hayes, 1986:94-98).

Miller probeer om verskeie faktore te isoleer wat 'n bepalende invloed op Israel se vroeë geskiedenis uitgeoefen het. Hy lê veral klem op die volgende faktore:

- Afname in Egiptiese invloed

Die geleidelike afname in die invloed wat Egipte op Kanaän uitgeoefen het gedurende die Laat Bronstyd. Die tanende invloed van Egipte word baie duidelik in onder andere die Amarnabriewe weerspieël. ${ }^{38}$

- Etniese verskeidenheid

Die bevolkingsamestelling van Kanaän gedurende die Laat Bronstyd word gekenmerk deur 'n groot verskeidenheid etniese groepe wat daar woonagtig was.

- Tanende invloed van Vasalkonings

Die afname van Egipte se mag in Kanaän het daartoe aanleiding gegee dat vasalkonings se heerskappy in sommige van die stadstate nie meer beskerm en in stand gehou kon word nie. Talle Kanaänitiese stadstate is in hierdie tyd verwoes. ${ }^{39}$ Gelyktydig hiermee vind daar 'n drastiese toename plaas in die getal nuwe nedersettings $\mathbf{4 0}$ wat veral in die gebiede opspring wat voor die aanvang van die Laat Bronstyd yl bevolk was. Die meeste stedelike nedersettings bestaan hoofsaaklik uit die saamgroepering van 'n aantal wonings. Van die 'groot stede' wat so kenmerkend was van die Vroeë en Middel Bronstyd het slegs enkeles gedurende die Laat Bronstyd nog bestaan.

38 Ten spye daarvan dat sekere farao's van die Negentiende Dinastie, naamlik Seti l, Raamses II en Merneptah in 'n mate die verlore aansien van Egipte herstel hel, was die oplewing net tydelik. Egipte het gedurende die Laat Bronstyd sy greep op Kanaän verlocor, al het hy nog aktiewe belange in Kanaan gehad tot so laat as 1150 v.C.

39 Enkele voorbeeld van Kanaänitiese stede wat gedurende die oorgang van die Laat Bronstyd na die Ysterlyd verwoes is, is Megiddo (Aharoni, 1977:830-856 en Schofield, 1976:316-321), Hasor (Yadin, 1972 en 1976:474-495), Afek (Eilan, 1975:70-73 en Kochavi, 1981:75-86), Tel Beit Mirsim (Albright, 1929:1-17 en 1967:207-220) ensovoorts.

40 Die meeste van die nuwe nedersettings het in die sentrale bergland ontstaan. Alhocwel hulle 'n merkbare lacr kuthuurpeil openbaar, is daar tog ook duidelike oorcenkomsic te bespeur met die nedersettings wat reeds aan die begin van die Laat Bronstyd ontstaan het (Miller \& Hayes, 1986:83). 
- Josua en Rigters nie ideale histories-venfieerbare bronne nie

Miller wys ook daarop dat die aard en inhoud van die historiese tradisies van die Ou Testament van so aard is dat dit nie moontlik is om die ontstaansgeskiedenis van Israel Jaaruit af te lei nie. Veral Josua en Rigters wat belangrike lig werp op die vroeë geskiedenis is nie ideale histories verifieerbare bronne nie omdat dit met verloop van tyd baie redaksionele veranderinge ondergaan het. Tog bly die bronne vir Miller van kardinale belang in die rekonstruksie van die oorsprong van Israel.

It is in our opinion in short, that the component narratives of the Book of Judges can serve
as a tenlative starting point for the treatment of Israclite and Judean history. While these
narratives will not, unfortunately, provide a basis for reconstructing any kind of detailed
historical sequence of people and events, they probably do offer a reasonably accurate
impression of the general sociological, political and religious circumstances that existed
among the early lsraelite tribes. (Miller \& Hayes, 1986:91.)

Dit is teen hierdie agtergrond dat Miller poog om die ontstaansgeskiedenis van Israel te rekonstrueer. ${ }^{41}$ Terwyl die finale redaktors van Genesis tot 2 Konings-tradisies 'n noue verbintenis tussen die twaalf stamme probeer weergee, het 'n noukeurige ondersoek van Josua en Rigters vir Miller tot die volgende konklusie gelei.

Miller wys daarop dat veral die stam van Efraim ${ }^{42}$ saam met Benjamin, Manasse en Gilead ' $n$ belangrike funksie vervul in die innametradisie soos wat dit in Josua en veral Rigters na vore kom (Miller, 1977b:279; Miller \& Hayes, 1986:94-98). Josua was na alle waarskynlikheid afkomstig uit die stam van Efraim. ${ }^{43}$ Die stam van Benjamin word meestal as 'n onafhanklike stam beskou, maar word soms saam met Gibea, Suidelike Efraim genoem. Stede wat volgens Josua 1-9 ingeneem is, is sonder uitsondering in die gebied van Benjamin geleë. Ander belangrike figure wat 'n rol speel in die vroeë geskiedenis van Israel is Ehud, Debora en Samuel. Saul, die eerste koning, is 'n lid van die stam van Benjamin.

Aan Manasse word 'n gebied toegeken wat strek vanaf ongeveer Sigem tot by die Jisreëlvlakte. Belangrike stede in die gebied is Bet-San, Megiddo en Ta'anak, stede wat nie deur die Israeliete ingeneem kon word nie (Miller \& Hayes, 1986:96). Israeliete wat hulle in die gebied gevestig het, was hoofsaaklik saamgetrek in die kleiner nedersettings wat in die gebied ontstaan het. Sporadiese kontak met die Galilea-/Jisreēlstamme, sowel as groepe in die Transjordaangebied het voorgekom. Samewerking en

\footnotetext{
41 In dié verhand is dit veral die wecrgawe van dic inname soos wat dit in Rigters voorkom, wat vir hom belangrike inligting bied.

42 Die sentrale tergland tussen Sigem en Silo is aan Efraim toegeken.

43 Josua 19:49-50 en 24:29-30 maak daarvan melding dal Josua na dic inname van dic land sy ciendom in dic gebied ontvang het en ook later hier begrawe is.
} 
kontak tussen die naasmekaarliggende Efraim en Manasse het gereeld plaasgevind. ${ }^{44}$ Dit is uit die innametradisie duidelik dat Efraim hierin 'n leidende rol geneem het.

Die patriargale verhale bevestig ook die leidende rol van Efraim ten opsigte van die ontstaansgeskiedenis van Israel. Jakob staan bekend as Israel en hy vestig hom in 'n gebied wat ooreenstem met die van Efraim. Josef en Benjamin, die jongste seun, word die gunstelingseuns van Jakob genoem. Efraim en Manasse word genoem as seuns van Josef, en Efraim die jongste, heers oor die oudste. Die oudstes van Efraim het onder leiding van Abner met Dawid onderhandel oor die koningskap wat hom aangebied is. $\mathrm{Na}$ die dood van Salomo sou Efraim die kern vorm van die Noordryk. 45 Wanneer die lys van Rigters wat in Rigters 10:1-5 en 12:8-15 genoem word, bestudeer word, is feitlik al die rigters afkomstig uit die gebied van Efraim/Manasse.

These Ephraimite/Israelite tribes command the center stage in the biblical tradilions pertaining to the premonarchical times. Other tribes appear on the periphery of things and usually come into consideration only when their interests overlap those of the Ephraimite/Israelite group. (Miller \& Hayes, 1986:98.)

Dit was hierdie alliansie van stamme ${ }^{46}$ wat die Merneptahstele bedoel met die verwysing na Israel in die stele (Miller \& Hayes, 1986:97).

Alhoewel Efraim, Manasse, Benjamin en Gilead nie in 'n goed georganiseerde verband saamgesnoer was nie, het Efraim telkens die leiding geneem wanneer die stamme saam moes optree. Die verbond van twaalf stamme ontwikkel evolusionêr uit die assosiasie van die vier stamme. In hierdie proses het verskillende faktore soos die topografie, die geografiese nabyheid van stamme, gedeelde belange, tipe leef- en bestaanswyse, die klimaat, religie, demografie en internasionale volkereverhoudinge en ekonomiese toestande 'n baie belangrike rol gespeel (Miller, 1977b:280) ${ }^{47}$ Oor die oorsprong, godsdiens en etnisiteit van die verskillende stamme is daar geen eenstem-

4 Miller wys daarop dat daar groot ontevredenheid van dic kant van Efraim was nadat Manasse, Aser, Naftali en Sebulon sonder die medewete van Efraim teen die Midianiete corlog gemaak het. Efraim is eers later daarvan in kennis gestel - 'n feil wat verhoudinge tussen dié st amme versuur het. Hieruit konkludeer Miller dat Efraim met dic inname van die Beloofde Land die inisiatief geneem het en dit behou het tydens die hele vestigingsproses wat daarop gevolg het. 'n Soortgelyke situasie heers na die optrede van (jilead onder leiding van Jefta toe Efraim gedreig het om Gilead aan te val omdat Efraim nic geken is in dic optrede teen die Ammoniete nie.

45 Dit interessant om daarop te wys dat wisselterme wat vir die Noordnyk gebruik word Efraim en Manasse is.

47 Hierdie siening van Miller verklaar ook waarom hy sovecl klem lì op die verwante vakdissiplines in die aavorsing oor die geskiedenis van lsrael. Dil dien naas die Ou Testament, as belangrike inligtingsbronne in die studie van die corsprong van Isracl. 
migheid nie. Dit is egter duidelik dat die stamme waaruit Israel evolusionêr ontwikkel het nie homogcen in hulle oorsprong, tradisies en religie was nie.

Callaway som die standpunt van Miller soos volg op:

These tribes were probably of diverse origins and ethnicity, as well as religion. Their emergence into a nation with a national religion was the result of a long process of struggle shaped by dynamic leaders we know as Judges, and externally by political pressures exericd primarily by the Philistincs. (Callaway, 1988:77-78.)

Dit is duidelik dat die Israeliete vir Miller (1977b:280) ontstaan uit verskeie groepe mense wat elkeen hulle eie kultuur, gebruike, leef- en bestaanswyse en godsdiens gehad het. Sommige van hierdie groepe was inheems aan Kanaăn terwyl sommige groepe sonder twyfel van buite Kanaänitiese grondgebied afkomstig was. Miller dink in dié verband aan 'n groep wat uit Egipte afkomstig was waar hulle as slawe vir die farao gedien het. Hierdie groep het tydens hulle ontsnapping uit Egipte en omswerwinge in die Arabiese woestyn unieke ervaring met 'n God gehad wat hulle Jahwe genoem het. Nog 'n groep was inheemse inwoners van Kanaän wat om verskeie redes hulle bestaande leefwyse vir' $n$ ander leefwyse verruil het. Hierdie verandering in die leefwyse het ook gepaardgegaan met 'n grootskaalse verhuising vanaf die digter bevolkte laerliggende gebiede na die yl bevolkte hoërliggende gebiede. 'n Ander groep was waarskynlik afkomstig uit 'n nomadiese swerwersgroep wat agter hulle kleinveetroppe rondgetrek het op soek na goeie weiveld. Hierdie nomadiese of semi-nomadiese groepe het hulle moontlik ook van tyd tot tyd skuldig gemaak aan rooftogte en die buit van eiendom van ander groepe mense soos dit duidelik blyk uit die Amarna-korrespondensie. Die verskillende groepe waaruit Israel ontstaan, kom nie gelyktydig hymekaar uit nie: die eenwordingsproses verloop oor etlike eeue. Die geskrewe historiese tradisies van die Ou Testament wat die oorsprong van Israel probeer weergee het, word eeue na die gebeure waarna daar in Josua 1-12 en Rigters 1-2 verwys word, op skrif gestel. Dit gee dan om bepaalde teologiese redes 'n verenigde prentjie van 'n kortstondige en eenvormige beginproses

Dit is duidelik dat Miller die agtergrond vir die oorsprong- en ontstaangeskiedenis as 'n baie komplekser aangeleentheid beskou as wat die Baltimore-, Leipzig- en Sosiologieskool dit verstaan het (Miller, 1977b:280). Uit die aard van dié omstandighede is Miller nie bereid om 'n spesifieke datum vir die ontstaan van Israel as etniese volk daar te stel nic. Die langdurige prosesse waardeur Israel groei, vind oor die loop van baie jare en dekades - moontlik eeue - plaas. Daarom moet die oorsprong van Israel, volgens Miller, nie gesoek word in 'n samebinding van stamme kort voordat hulle met 'n pan-Israelitiese (weer)mag Kanaän in 'n betreklike kort tyd verower nie. Die Israelitiese nasionale bewussyn waaruit Israel groei en ontstaan, was eerder geleë in die gemeenskaplike belange en struikelblokke van die individuele stamme wat as gevolg van oorlewing oor 'n baie lang tydperk met mekaar begin assosieer het. 
Miller wil die ontstaangeskiedenis van Israel nie alleen verstaan vanuit die blote lees van die Ou Testament nie, of deur die gebruikmaking van sekere verwante vakdissiplines nie. 'n Noukeurige en objektiewe lees van Josua en Rigters is 'n noodsaaklike vereiste vir die rekonstruksie van die oorsprong van Israel. Hierdie data moet egter aangevul word deur ' $n$ noukeurige studie van ander verifieerbare veranderlikes, deur gebruik te maak van ander wetenskaplike navorsingdissiplines. Wanneer alle kontroleerbare gegewens bestudeer is, moet daaruit 'n konklusie getrek word. Op hierdie wyse probeer Miller om 'n breë scenario te skets van die omstandighede en agtergrond waarin Israel sy oorsprong gevind het. Die gevolgtrekking waartoe Miller kom, is dat Israel sy ontstaan of oorsprong vind in die smeltkroes-omstandighede (melting pot) wat gedurende die oorgang van die dertiende na die twaalfde eeu v.C. in Kanaăn geheers het. Verskeie faktore wat ekonomies, polities en sosiaal van aard was, het gesamentlik en afsonderlik 'n bepalende invloed uitgeoefen op die ontstaan van die etniesdefinieerbare groep, bekend as Israel. Hierdie nuwe etniese gemeenskap wat later'n religieuse gemeenskap word, het sy regmatige plek ingeneem in die geskiedenis van die hele Ou Nabye Ooste soos wat dit duidelik blyk uit die geskiedenis van die konings van die Noord- en Suidryk.

Die benadering van Miller rakende die ontstaansgeskiedenis van Israel weerspieël duidelik dat hy bewus is van die problematiek rondom die rekonstruksie van die geskiedenis van Israel voor die totstandkoming van die Monargie. Die bronne waarmee die historici werk, is nie deurgaans histories-verifieerbare bronne nie. Daarom beklemtoon Miller dit dat ook sy model vir die oorsprong van Israel bloot 'n hipotese is, en so sal bly totdat dit deur meer betroubare en verifieerbare bronne bevestig word (Miller, 1982:215-216). Miller hou in sy interpretasie van die Ou Testament as belangrikste bron oor die vroeë geskiedenis van Israel rekening met die teologiese boodskap wat die bron dra. Hy hanteer nie die bron as ' $n$ suiwer historiese bron nie, maar as ' $n$ bron wat 'n bepaalde teologiese boodskap wou tuisbring.

Hierdie probleme veroorsaak by Miller ' $n$ huiwering om van 'n geskiedenis van Israel voor die totstandkoming van die Monargie te praat. Vir die daarstelling van so 'n geskiedenis beskik historici eenvoudig nie oor genoeg bronne nie. Uit die baie beperkte bronne tot sy beskikking is Miller egter daarvan oortuig dat Israel se oorsprong in 'n heterogene samelewing geleë is. ${ }^{45}$ Hy kan alleen maar poog om op grond van die Ou Testament, die argeologie en ander verwante vakdissiplines toestande wat gedurende die Laat Bronstyd en Ystertyd geheers het, te rekonstrueer. Daaruit poog hy dan om konklusies te trek oor hoe die eerste Israeliete gelewe en

48 Dit is vir Miller een van die enigste punte waarvan hy haie scker is en wat uil sy navorsing na vore gekom het. "Palestine at the time was something of a melting $p$ x conımosed to diverse elements living under various ad hoc political and religious circumstances." (Miller \& Hayes, 1986:78.) 
gewerk het. Dit is juis dié benadering wat verklaar waarom Miller nie van die Mosestradisie in die Ou Testament gebruik maak in sy navorsing oor die vroeë geskiedenis van Israel nie.

Die benadering van Miller verdien ons ernstige oorweging aangesien dit baie duidelik is dat Miller in sy benadering oor die rekonstruksie van die vroeë geskiedenis van Israel baie konserwaticf te werk gaan. Miller maak hom nie skuldig aan akademiese opportunisme nie. Hy maak geen wilde spronge in sy navorsing nie en huiwer nie om cerder 'n hipotese daar te stel waarvan hy self sê dat dit niks meer as 'n hipotese is nie. Die geweldige hoë premie wat hy op die Ou Testament plaas, ten spyte van die probleme wat daar aan die gebruikmaking van die bron verbonde is, moet gewaardeer word.

Die belangrikste kritiek wat teen Miller ingebring kan word ten opsigte van sy benadering, is sy algehele verwerping van die Moses-tradisie in die Pentateug as belangrike bron vir die vroeë geskiedenis van Israel. Die wyse waarop hy van die Rigters-tradisie en Josua-tradisie gebruik maak in sy navorsing, laat onmiddellik die vraag ontstaan waarom hy nie ook hoë waarde heg aan die Moses-tradisie wat tog belangrike inligting bied nie.

\section{GEVOLGTRLKKING}

Die positiewe bydrae wat die argeologie gelewer het in die navorsing oor die oorsprong van Israel en die geskiedenis van Israel voor die totstandkoming van die Monargie mag nie onderskat of geminimaliseer word nie. Dit is egter van baie groot belang dat die argeologie nooit meer as 'n toeligtingsrol mag speel nie. Waar die argeologie gebruik word om die Bybelse tradisie te waarmerk, moet dit sterk afgewys word. Die argeologie speel egter ' $n$ belangrike rol in die skepping van 'n breë scenario van die toestande wat in Kanaän geheers het gedurende die Laat Bronstyd en Yster I-tyd. Dit was in hierdie omstandighede dat Israel as etniese volk sy wortels het en waaruit die stammeverbond later gegroei het.

Die rol wat ander vakdissiplines soos die Ekonomie, Staatsleer, Sosiologie, Geografie, Demografie, ensovoorts speel in die navorsing oor die geskiedenis van Israel is belangrik aangesien dit bydra tot die daarstelling van die agtergrond waarteen Israel sy oorsprong vind. Dit is egter belangrik dat die vakdissiplines nie onafhanklik en geisoleerd van die Ou Testament en argeologie bestudeer moet word nie.

Wanneer die totale scenario waarin Israel sy oorsprong gehad het in oënskou geneem word, kan die oorsprong van Israel nie aan een besondere gebeurtenis toegeskryf word nie. Israel is die produk van baie gebeure wat op mekaar ingewerk het. Dit onderstreep die kompleksiteit van die probleem vir elkeen wat navorsing doen oor Israel se 
ontstaansgeskiedenis. Wie dink dat hy met groot stelligheid die geskiedenis van Israel kan rekonstrueer, sal sonder enige twyfel teleurgestel word. Dit sou veel beter wees om die volgende vertrekpunt in ag te neem met die daarstelling van die ontstaansgeskiedenis van Israel.

- Noodsaaklikheid van 'n breë bestuderingshoek

Israel se ontstaansgeskiedenis kan hoogstens by benadering daargestel word wanneer die omstandighede en agtergrond waarin Israel sy oorsprong het, gerekonstrueer kan word. Vir hierdie doel moet alle bestaande historiese en argeologiese bronne vanuit 'n wyer gesigshoek benader word as wat voorheen die geval was. ${ }^{49}$ Alle kontroleerbare gegewens ${ }^{50}$ wat gedurende die Iaat Bronstyd en Yster l-tyd die fisiese omgewing van Kanaän sowel as sy inwoners beïnvloed het, 51 moet bestudeer word.

- Oorsprong van Israel: 'n smeltkroes van omstandighede

Wanneer die bogenoemde faktore in ag geneem word, sou dit die beste wees om van die veronderstelling uit te gaan dat Israel sy oorsprong in die smeltkroes van omstandighede tydens die oorgang van die Laat Bronstyd na die Yster I-tyd gevind het. Alhoewel sommige van die eerste Israeliete moontlik wel mense was wat 'n nomadiese of semi-nomadiese leefwyse in die Arabiese woestyn gevoer het, was nie ál die Israeliete aanvanklik uit die gebied afkomstig nie. ${ }^{52}$ Die Israeliete vind ook nie nét hulle oorsprong in die ontevrede en onderdrukte burgers van die Kanaänitiese stadstate nie. ${ }^{53}$ Toestande op ekonomiese, sosiale en staatkundige gebied het aanleiding gegee tot die 'geboorte' van 'n nuwe volk waarmee God sy herskepping begin het.

49 Hier word verwys na die wyse waarop byvoorbeeld die Baltimoreskool gehruik gemaak het van die argeologie as vakwetenskap en die Leipzig- en Sosiologieskool van die Bybelse en buite-Bybelse literêre bronne en ander vakdissiplines.

so In die verband kan melding gemaak word van die klimaat, die bodemgesteluheid van die gebied, produkte wat verbou is, die tipe vec waarmee geboer is, tegnologiese ontwikkeling wat die leefwyse van die mense vergemaklik het en hulle in staat gestel het om hulle in gebiede te vestig waar permanente vestiging voec̄r heeltemal onmoontlik was, die sosiale strukture wat die lewe en verhoudinge tussen mense georden en op 'n vasle grondslag geplaas het, die internasionale verhoudinge tussen onafhanklike etniese grope, ensovoorts.

51 Dit het betrekking op die inwoners se leefwyse, hoe hulle 'n bestaan gemaak het en watter strukture hulle daargestel het om hulle daaglikse lewe te orden.

52 Hierdie standpunt word veral gehandhaaf deur die Baltimore-en Leiprigsknol. Die Leipzigskool is egter meer soepel in hulle standpunt oor die herkoms van die eerste Israeliete.

53 Dit was die vertrekpunt van die Sosiologieskool. 


\section{BIBLIOGRAFIE}

AHARONI, A. 1971. The Settlement in Canaan. (In Mazar, B. ed. The World History of the Jewish Pcoplc. Jcrusalcm : Massada Publishing Co. p. 94-129.)

AHARONI, A. 1976. Nothing Early and Nothing Latc: Re-writing Isracl's Conquest, Biblical Anchoeologist, 39:55-76.

AHARONI, A. 1977. Mcgiddo. (In Avi-Yonah, M. \& Sicrn, E. eds. Encyclopedia of Archacological Excavations in the Holy Land. Vol. 3. London : Oxford University Press. p. 830-856.)

AHLSTRöM, G.W. 1982. Where did the Israclites Live? Joumal of Near-Eastem Studies, 41:133-138.

AHLSTRóM, G.W. 1986. Who were the Israclites? Winoa Lake : Eisenbrauns.

AHLSTRó, G.W. 1990. Diffusion in Iron Age Palcstinc: Some Aspects. Scandinavian Joumal of the Old Testament, 1:81-105.

ALBRIGHT, W.F. 1929. The Amcrican Excavations at Tell Bcit Mirsim. Zeitschrift fïr die altiestamentliche Wissenschaft, 47:1-17.

ALBRIGiHT, W.F. 1935. Archacology and the Date of the Conquest Palcstinc. Bulletin of the American Schools of Oriental Reseanch, 58:10-18.

ALBRIGHT, W.F. 1937. Further Light on the History of Istael from Lachish and Mcgiddo. Bulletin of the American Schools of Oriental Research, 68:22-26.

ALBRIGHT, W.F. 1939. The Israclite Conquest of Canaan in the Light of the Archacology. Bulletin of the American Schools of Oriental Research, 74:11-23.

ALBRIGHT, W.F. 1967. Debîr. (In Winton Thomas, D. ed. Archacology and Old Testament Study. Oxford : Clarendon Press. p. 207.220.)

ALBRIGHT, W.F. 1971. The Archacology of Palestine. Gloucester : SCM Press.

ALT, A. 1953a. Klcine Schriften zur Geschichte des Volkes Israel. Vol. I. München : C.B. Beck'sche Verlagsbuchhandlung.

ALT, A. 1953b. Erwägungen ülser die Landnahme der Isracliten in Palästina. (In Alı, A. Kleine Schriften zur (ieschichte des Volkes Isracl. Vol. I. München : C.B. Beck'sche Verlagsbuchhandlung. p. 126-157.)

ALT, A. 1953c. Joshua. (In Alt, A. 1953a. Kleine Schriften zur Geschichte des Volkes Isracl. Vol. I. München : C.B. Beck'sche Verlagsbuchhandlung. p. 176-192.)

ALT, A. 1953d. Die Landnahme der Isracliten in Palästina. (In Alt, A. 1953a. Klcine Schriften zur Geschichte des Volkes Israel. Vol. I. München : C.B. Beck'sche Verlagsbuch handlung. p. 89 125.)

ALT, A. 1966. The Settlement of the Israclites in Palestine. (In Alt, A. Essays on Old Testament History and Religion. Oxford : Basil Blackwell. p. 135-169.)

BEN TOR, A. 1979. Tell Qiri: A Look at Village Life. Biblical Archaeologist, 42:105-113.

BIMSON, JJ. 1978. Redating the Exodus and Conquest. (In Clines, D.J.A., Davies, P.R. \& Gunn, D.M. eds. Journal for the Study of the Old Testament Supplement Series 5. Sheflicld : The Almond Press.)

BIMSON, J.A. 1989. The Origins of Isracl in Canaan: An Examination of Recent Theories. Themelios, $15(1): 4-15$.

BRIGHT, J. 1981 ${ }^{3}$. The History of Isracl. London : SCM Press.

CALLAWAY, J.A. 1968. New Evidence on the Conquest of Ai. Joumal of Biblical Literature, 87:312-320.

CALlaway, J.A. 1988. The Settlement in Canaan: The Period of the Judges (In Shanks, ed. H. Ancient Isracl. A Short History from Abraham to the Roman Destruction of the Temple. Washington: Biblical Archacology Socicty. p. 53-84.)

CHANEY, M.L. 1983. Ancient Palestine Peasants Movements and the Formation of Pre-Monarchic Isracl. (In Freedman, D.N. \& Graf, D.F. eds. Palestine in Transition. The Emergence of Ancient Isracl. Shefficld : The Almond Press. p. 39-90.)

DE GEUS, C.HJ. 1976. The Tribes of Isracl. An Investigation into some Presuppositions of Martins Noth's Amphictyony Hypothesis. Assen : Studii Semitica Ncerlandica 18. 
DE VAUX, R. 1978. The Early History of Israel. London : Darton, Longman \& Todd.

DEVER, W.G. 1990. Recent Archaeological Discoveries and Biblical Research. Seattle / London : University of Washington Press.

DONNER, H. 1984. Geschichte des Volkes Israel und seiner Nachbarn in Grundzügen. Göttingen : Van den Hoeck un Ruprecht.

EITAN, A. 1975. Ahek. (In Avi-Yonah, M. ed. Encyclopedia of Archaeological Excavations in the Holy Land. Vol. I. London : Oxford University Press. p. 70-73.)

FINKELSTEIN, I. 1988a. Searching for Israelite Origins. Biblical Anchaeology Review, 14(5):34.45.

FINKELSTEIN, I. 1988b. Archaeology and the Israelite Settlement. Jerusalem : Isracl Exploration Society.

FOHRER, G. 1977. Geschichte Israels. Van den Anfängen bizz zur Gegenwart. Heidelberg : Quelle \& Meyer.

FRITZ, V. 1980. Die kulturhistorische Bedeutung des früheisenzeitichen Siedlung auf de Hirbet el-Msas und das Problem der Landnahme. ZDPV, 96:121-135.

FRITZ, V. 1981. The Israelite Conquest in the Light of Recent Excavations at Khirbet el Meshash. Bulletin of the American Schools of Oriental Research, 241:61-73.

FRITZ, V 1983. The Conquest in the l.ight of the Archacology. (In Proceedings of the Eight World Congress of Jewish Studies, 1982. Jerusalem : Isracl Exploration Socicty. p. 15-21.)

FRITZ, V. 1987. Conquest or Settlement: The Early Iron Age in Palestine. Biblical Archaeologist, $\operatorname{SOM}(2): 84-100$.

GOTTWALD, N.K. 1974. Were the Early Israelites Pastoral Nomads? (In Jackson, J. \& Kessler, M. eds. Rhetorical Criticism: Essays in Honor of James Muilenberg Pittsburg : The Pickwick Press. p. 223-255.)

GOTTWALD, N.K. 1975. Domain Assumptions and Societal Models in the Study of Pre-Monarchic Israel. Vetus Tesiamentum Supplementum, 28:89-100.

GOTTWALD, N.K. 1978a. Were the Early Israelites Pastoral Nomads. Biblical Archaeology Review, 4(2):2-7.

GOTTWALD, N.K. 1978b. The Hypothesis of the Revolutionary Origins of Israel: A Response to Hauser and Thompson. Joumal for the Study of the Old Testament, 7:37-52.

GOTTWALD, N.K. 1979. The Tribes of Yahweh: A Sociology of the Religion of I.iberated Israel 1250100 BCE. London : SCM Press.

GOTTWALD, N.K. 1983. Two Models for the Origins of Ancient Israel: A Social Revolution and Frontier Development. (In Huffmon, H.B., Spina, F.A. \& Green, A.R.W. eds. The Quest for the Kingdom of God. Studies in Honor of George E. Mendenhall. Winoa Lake : Eisenbrauns. p. 5-24.)

GOTTWALD, N.K. 1985. The Israelite Settlement as a Social Revolutionary Movement. (In Bíblical Archacology Today: Proceedings of the International Congress on Biblical Archacology Jerusalem, April 1984. p. 34-46.)

GUNNEWEG, A.H.J. 1972. Geschichte Israels bis Bar Kochba. Stuttgart : W. Kohlhammer.

HALPERN, B. 1983. The Emergence of Israel in Canaan. Chico : Scholars Press.

HAUSER, A.J. 1978. Israels Conquest of Palestine. A Pcasant's Retcillion. Joumal of the Study of the Old Testament, 7:2-19.

HER RMANN, S. 1985. Basic Factors in the Israelite Settlement. (In Biblical Archacology Today: Proceedings of the International Congress on Biblical Archaeology, Jerusalem April 1984, p. 47. 53.)

HODDER, I. 1984. Archaeology in 1984. Antiquity, 58:25-31.

KOCHAVI, M. 1981. The History and Archaeology of Aphek-Antiparis: A Biblical City in the Sharon Plain. Biblical Anchaeologist, 44:75-86

LAPP, P.W. 1967. The Conquest of Palestine in the Light of the Archaeology. Concordia Theological Monthly, 38:283-300. 
LEMCHE, N.P. 1984. Israel in the Period of the Judges: The Tribal League in Recent Research. Studia Theologica, 38:1-28.

LEMCHE, N.P. 1985. Early Israel: Anthropological and Historical Studies on the Israclitc Society before the Monarchy. Leiden : E.J. Brill.

LEMCHE, N.P. 1987. Rachel and Lca. Or: On the Survival of Outdated Paradigmas in the Study of the Origin of Isracl I. Scandinavion Joumal of the Old Testament, 2:127-153.

LEMCHE, N.P. 1991. The Canaanites and their land. The Tradition of the Canaanites (Joumal for the Study of the Old Testament Supplement Series, 110.) Sheffield : JSOT Press.

LEONARD, A. jr. 1989. The Late Bronze Age: Archacological Sources for the History of Palestine. Biblical Archaeologist, 52(1):4-39.

LONDON, G. 1989. A Comparison of Two Contemporaneous Lifestyles of the Second Millennium B.C.. Bulletin of the American Schools of Oriental Research, 273:37-55.

MAL_AMAT, A. 1982. How Inferior Israelite Forces Conquered Fortified Cananite Cities. Biblical Anchaeology Review, 8(2):25-35.

MASAR, A. 199). Archacology of the Land of the Bible 10 000-586 BCE. (Anchor Bible Reference Library.) New York : Doubleday.

MENDENHALL, G.E. 1962. The Hebrew Conquest of Palestinc. Biblical Archaeologist, 25:66-87.

MENDENHALL, G.E. 1973. The Tenth Generation: The Origins of Biblical Tradition. London : Johns Hopkins University Press.

MILLER, J.M. 1977a. Archacology and the Israelite Conquest of Canaan: Some Methodological Observations. Palestine Exploration Quarerly, 109:87-93.

MILLER, J.M. 1977b. Isracls Occupation of Canaan. (In Miller, J.M. \& Hayes, J.H. 1977. Israclite and Judean History. London : SCM Press. p. 213-284.)

MILLER, J.M. 1982. Approaches to the Bible through History and Archacology: Biblical History as a Discipline. Biblical Archaeologist, 54:211-216.

MILLER, J.M. 1985. Israelite History. (In Knight, D. \& Tucker, G.M. eds. The Hebrew Bible and its Modern Interpretcrs. Philadelphia : Fortress Press. p. 43-52.)

MILLER, J.M. \& HAYES, J.H. 1986. A History of Ancient Isracl and Judah. London : SCM Press.

MILLER, J.M. 1990. The Wilness of Ai. (Unpublished paper.)

NOORT, E. 1987. Geschiedenis als brandpunt over de rol van de archcologic bij de vestiging in Kanaan GTT, 87(2):84-102.

NOTH, M. 1930. Das System der zwöll Stầmme Isracls. (In BWANT, IV/1.)

NOTH, M. 1960a. Dic Beitrag der Archälogie zur Geschichte Israels. Supp. Vetus Tesiamentum, 7:262282.)

NOTH, M. $19(x)^{2}$ b. A History of Isracl. London : Adam, Charles \& Black.

OLIVIER, H. 1989. Die mensbecld in die skeppingsverhale van Genesis. Tydskrif vir Semitistiek, 1:71-87.

OTTO, E. 1988. Stadt und Land im spātbronzezeitlichen und früheiscnzeillichen Palästina. Zur Methodik der Korrelierung von Geographic und Antiker Religionsgeschichte. (In Rudolph, K. \& Rinschede, G. eds. Geographia Religionum. Berlin : Dictrich Reimer Verlag. p. 225-241.)

PIENAAR, D.N. 1990. Bybelse Argeologic en dic Ou-Testamentiese geskiedskrywing. Ned Geref Teologiese Tydskif 21(3):310-318.

SAUER, J.A. 1982. Syro-Palestinian Arthacology, History and Biblical Studies. Biblical Archaeologist, 45:201-209.

SCHOFIELD, J.N. 1967. Megiddo. (In Winton Thomas, D. ed. Archaeology and Old Testament Study. Oxford : Clarendon Press. p. 309-328.)

SHILOH, Y. 1970. The Four Room House. Situation and Function in the Israclite City. Israel Exploration Joumal, 20:180-190.

SOGGIN, J.A. 1960. Ancient Biblical Traditions and Modern Archacological Discoveries. Biblical Archacologist, 42:95-100.

STIEBIN(i, W.H. (jr.) 1989. Out of the Desert? Archacology and the Exodus/Conquest Narratives. New York : Prometheus Books. 
THOMPSON, T.L. 1978. Historical Notes on "Isracls" Conquest of Palestine: A Peasant's Rebellion. Joumal for the Study of the Old Testament, 7:20-27.

VAN DER WESTHUIZEN, NJ.G. 1991. Israel in Kanaän: 'n Histories-argeologiese ondersoek na die vestiging van die Isracliete in die Yster I-Tyd. Stellenbosch. (Ongepublisecrde proefskrif (D Th. - US).

WALTKE, B.K. 1972. Palestinian Artifactual Evidence, the Early Date of the Exodus. Bibliotheca Sacra, 129:38-47.

WEIPPERT, M. 1971. The Settlement of the Israelite Tribes in Palestine. London : SCM Press.

WEIPPERT, M. 1979. The Israelite Conquest and the Evidence from Transjordan. (In Cross, F.M.ed. Symposia Celebrating the Seventy-Fifih Anniversary of the American Schools of Oriental Research, 1900-1975. Cambridge. p. 15-34.)

WOLFF, E.R. 1966. Peasants. Englewood Cliffs : Prentice-Hall.

WOOD, B.G. 1990. Did the Israelites Conquer Jericho? Biblical Archaeology Review, 16(2):44-58.

WRIGHT, G.E. 1946. The Literary and Historical Problem of Joshua 10 and Judges 1 . Joumal for the Study of the Old Testament, 5:105-114.

YADIN, Y. 1972. Hazor: The Schweich Lectures. London : Oxford University Press.

YADIN, Y . 1976. Hazor. (In Avi-Yonah, M. ed. 1976. Encyclopedia of Archaeological Excavations in the Holy Land. Vol. 2. London : Oxford University Press. p. 474-495.)

YADIN, Y. 1982. Is the Biblical Account of the Conquest of Canaan Historically Reliable? Biblical Aschaeology Review, 8(2):17.23.

ZERTAL, A. 1986. The Israelite Settlement in the Hill Country of Mannassch. Tel Aviv. (Thesis - Ph.D. - Tel Aviv University.) Hebrew with English abstract. 